Abstracta Iranica Abstranica

Revue bibliographique pour le domaine irano-aryen

Volume 32-33 | 2013

Comptes rendus des publications de 2009-2010

\title{
Uzi Rabi, Nugzar Ter-Oganov. The Russian Military Mission and the Birth of the Persian Cossack Brigade:
} 1879-1894

Denis Hermann

\section{(2) OpenEdition Journals}

Édition électronique

URL : http://journals.openedition.org/abstractairanica/40680

DOI : $10.4000 /$ abstractairanica. 40680

ISSN : 1961-960X

Éditeur :

CNRS (UMR 7528 Mondes iraniens et indiens), Éditions de l'IFRI

\section{Édition imprimée}

Date de publication : 1 décembre 2013

ISSN : 0240-8910

Référence électronique

Denis Hermann, "Uzi Rabi, Nugzar Ter-Oganov. The Russian Military Mission and the Birth of the Persian Cossack Brigade: 1879-1894 ", Abstracta Iranica [En ligne], Volume 32-33 | 2013, document 254, mis en ligne le 01 juillet 2016, consulté le 27 septembre 2020. URL : http://journals.openedition.org/ abstractairanica/40680 ; DOI : https://doi.org/10.4000/abstractairanica.40680

Ce document a été généré automatiquement le 27 septembre 2020.

Tous droits réservés 


\title{
Uzi Rabi, Nugzar Ter-Oganov. The Russian Military Mission and the Birth of the Persian Cossack Brigade: 1879-1894
}

\author{
Denis Hermann
}

\section{RÉFÉRENCE}

Uzi Rabi, Nugzar Ter-Oganov. «The Russian Military Mission and the Birth of the Persian Cossack Brigade: 1879-1894 ». Iranian Studies, 42/3, 2009, p. 445-463.

1 Cet article revient sur les premières quinze années de la constitution de la brigade cosaque persane en Iran, entre 1879 et 1894, à la lumière de sources russes méconnues. Pour la première fois l'Iran faisait appel à des instructeurs militaires russes après avoir accueilli des Français, des Britanniques, des Autrichiens et des Italiens. De nombreux travaux existent maintenant sur le rôle central de la brigade au cours du début du $\mathrm{XX}^{\mathrm{e}}$ s., en particulier dans la répression des forces pro-constitutionnalistes à Téhéran ainsi que lors du coup militaire de Reḍā Hูān (m. 1944) en 1921.

2 Les AA. soulignent en particulier les politiques menées par les premiers commandants russes de cette brigade. Il s'agit du Général Frankini qui visita l'Iran en 1877-78 pour une première mission de repérage, le lieutenant-colonel Aleksei Domantovich qui devint le premier commandant de ce nouveau corps d'élite entre 1879 et la fin de 1881, le colonel Charkovskii qui lui succéda entre 1882 et 1885, le colonel Kuzmin-Karavaev qui remplaça ce dernier de 1885 à 1890 , le colonel Shneur qui assuma à son tour cette position de 1890 à 1893 et enfin le colonel V. A. Kosogovskii à partir de 1894.

Une grande place est accordée dans l'article à l'organisation de la brigade, aux questions de recrutement et de financement en particulier. Les AA. soulignent à ce titre que c'est essentiellement des mohājer musulmans du Caucase qui intégrèrent ce corps 
d'élite. Ces derniers recevaient un meilleur salaire que les volontaires qualifiés de " būmī » (autochtone). Les AA. concluent l'article sur les raisons du déclin de la brigade après le départ de Domantovich en 1881.

\section{AUTEURS}

\section{DENIS HERMANN}

CNRS/Mondes iranien et indien, Paris 